https://doi.org/10.31108/2.2021.4.24.10

УДК $159.923: 316.613: 005.95$

\title{
Marianna Tkalych
}

\section{WORK-LIFE BALANCE PROGRAMS AS PERSONNEL SOCIAL AND PSYCHOLOGICAL SUPPORT IN ORGANIZATIONS} \author{
organizations. \\ Tkalych, Marianna. Work-life balance programs as personnel social and psychological support in
}

Introduction. Today work environment becomes stressful, with many tasks and problems to solve. It is overloaded, imbalanced, complicated and often full of conflicts. In this climate, managing the boundary and balance between home and work is becoming more challenging. There is a need for organizations and personnel alike to find flexible and innovative solutions that maximize productivity without damaging personnel' well-being, their personal life, family relationships.

Aim. To analyse the main categories, resources and limitations of work-life balance, results of empirical study, main organizational and individual strategies for creating balance.

Results. Work-life balance is a category defined by researchers as a person's subjective general assessment of the interrelation between work and other life areas, family, as well as the ability to combine these spheres in a proper way. The empirical study has shown, that the work-life balance has been generally assessed as average. It should be noted that they have scored the load balance lower than other components: professional tasks complexity, work and content planning, and social intercourse. According to the results of the empirical study and to the theoretical approaches, the basic strategies in professional productivity increase programs in organizations may be the following: focus strategies, "resource/refusal" strategies, adaptive strategies, every of which is manifested in a certain kind of an individual strategy. The use of the adaptive individual strategies with the resource increase strategy perfectly contributes to the work-life balance achievement.

Conclusion. Based on the results of theoretical and empirical research, we have identified organizational conditions and individual strategies for achieving the work-life balance, and also the main personal skills and traits contributing to the work-life balance achievement include the following ones: personal flexibility, a high level of selfdiscipline; trust-based relations; dynamic and independent work. These skills should be mature, and the work-life balance achievement psychological teaching programs for personnel can increase their level.

Key words: work-life balance, social and psychological support, personnel, work-life enrichment, work-life conflict, individual balance strategies.

Ткалич Маріанна. Програми балансу «робота - жсття» як соціальна та психологічна підтримка персоналу в організаціях.

Bступ. Сьогодні робоче середовище стає напруженим, змушує вирімувати багато завдань та проблем. Воно перевантажено незбалансоване, складне і часто сповнене конфліктів. У цььому кліматі управління межами $і$ балансом між різними сферами життя і роботою стає все складнішим. Потрібно, щуоб організації та персонал знаходили гнучкі та інновачійні рішення, які б збільщували продуктивність прачі без шкоди для психологічного благополуччя персоналу, його особистого життя та сімейних стосунків.

Мета Проаналізувати основні категорії, ресурси та обмеження балансу між роботою та іншими сферами життя, результати емпіричного дослідження, основні організаційні та індивідуальні стратегії створення балансу.

Результати. Баланс між робочим та особистим життям - ие категорія, визначена дослідниками як суб'єктивна загальна оцінка людиною взаємозв'язку між роботою та іншими сферами життя, сім'єю, а також здатність належним чином поєднати ці сфери. Емпіричне дослідження показало, щьо баланс роботи та особистого життя в иілому оцінюється як середній. Респонденти оиінили баланс навантаження нижче, ніж інші складові: складність професійних завдань, планування роботи та змісту, а також соціальні стосунки. Відповідно до результатів емпіричного дослідження та теоретичних підходів, основними стратегіями в програмах підвищення професійної продуктивності в організаціях можуть бути такі: стратегї̈ фокусування, стратегії «ресурсу/відмови», адаптивні стратегії, кожна з яких проявляється у індивідуальних стратегіях. Використання адаптивних індивідуальних стратегій зі стратегією збільшення ресурсів чудово сприяє досягненню балансу між роботою та особистим життям.

Висновки. На основі результатів теоретичних та емпіричних досліджень ми визначили організаційні умови та індивідуальні стратегії досягнення балансу робота - життя, а також основні особисті навички та риси, ще сприяють досягненню балансу робота - життя, включають наступні: особиста гнучкість, високий рівень самодисципліни; відносини, засновані на довірі; динамічна та незалежна робота. Ці навички мають бути зрілими, а програми психологічного навчання персоналу для досягнення балансу робота - життя можуть підвищити їх рівень. 
Ключові слова: баланс "робота - життя», сочіальний та психологічний супровід, персонал, збагачення професійного та професійного життя, конфлікт між професійним та особистим життям, індивідуальні стратегії балансу.

Ткалич Марианна. Программы баланса «работа-жизнь» как социальная и психологическая поддержка персонала в организациях.

Введение. Сегодня рабочая среда становится напряженной, заставляет решать многие задачи и проблемы. Она перегруженная, несбалансированная, сложная и часто полона конфликтов. В этом климате управлять границами и балансом между сферами жизни и работой становится все сложнее. Необходимо, чтобы организации и персонал находили гибкие и инновационные решения, которые увеличивали производительность труда без ущерба для психологического благополучия персонала, его личной жизни и семейных отношений.

Цель. Проанализировать главные категории, ресурсы и ограничения баланса меж работой и другими сферами жизни, результаты эмпирического исследования, главные организационные и личные стратегии сотворения баланса.

Результаты. Баланс между рабочей и личной жизнью - это категория, определенная исследователями как субъективная общая оценка человеком взаимосвязи между работой и другими сферами жизни, семьей, а также способность должным образом соединить эти сферы. Эмпирическое исследование показало, что баланс «работа - жизнь» в иелом оценивается как средний. Респонденты оценили баланс нагрузки ниже других составляющих: сложность профессиональных задач, планирование работы и содержания, а также соииальные отношения. Согласно результатам эмпирического исследования и теоретических подходов, основными стратегиями в программах повышения профессиональной производительности в организациях могут быть: стратегии фокусировки, стратегии «ресурса/отказа», адаптивные стратегии, каждая из которых проявляется в индивидуальных стратегиях. Использование адаптивных индивидуальных стратегий со стратегией увеличения ресурсов отлично способствует достижению баланса между работой и личной жизнью.

Выводы. На основе результатов теоретических и эмпирических исследований мы определили организационные условия и индивидуальные стратегии достижения баланса "робота - жизнь», а также основные личные навыки и черты, способствующие достижению баланса робота - жизнь, включают: личную гибкость, высокий уровень самодисциплинь; отношения, основанные на доверии; динамическая и независимая работа. Эти навыки должны быть зрельми, а программы психологического обучения персонала для достижения баланса работа - жизнь могут повысить их уровень.

Ключевые слова: баланс "работа - жизнь», сочиальное и психологическое сопровождение, персонал, обогащение профессиональной и профессиональной жизни, конфликт между профессиональной и личной жизнью, индивидальные стратегии баланса.

Introduction. Nowadays, people's lives as well as their professional and personal development are being affected by a lot of various factors, events, information flows, and tasks, which they face every day. Professional development and productivity increase are associated not only with staff's abilities and skills as well as their career goals and motivation, but also with the ability for time and energy management (the ability to divide one's time and energy between work and leisure). The efficiency and productivity, the ability to achieve strong performance, and, along with it, the satisfaction with life and harmonious development are of great significance.

Over the past three decades, the issues of work-life balance have drawn researchers' attention all over the world, but not in Ukraine. Today, work environment becomes stressful, with many tasks and problems to solve. It is overloaded, imbalanced, complicated and often full of conflicts. In this climate, managing the boundary and balance between home and work is becoming more challenging. There is a need for organizations and personnel alike to find flexible and innovative solutions that maximize productivity without damaging personnel' well-being, their personal life, family relationships.

The need for work-life balance programs in psychological and organizational support of personnel is due to the following changes in the social, economic and psychological conditions of organization activities:

- demographic and social changes that led to an increasing number of women in the professional sphere, to the appearance of working mothers with infants, who have become the norm and not the exception, to rising of the average age of employees;

- development of technologies (mobile telephones, Internet, email) that ensure reconciliation of work and personal and family life, can help to organize the work away from the workplace;

- modern challenges, that have increased requirements for flexibility of employees and organizations to increase their capacity to respond to changes;

- the increasing number of employees with more than one job;

- the increasing of working hours, leading to personnel overload and therefore the working environment becomes more stressful and requires a "discharge." 
When a company does not take work-life balance into account, some symptoms could turn up: women might not come back to the workplace after maternity leave; high stress levels might occur among the personnel; employees might demand flexible strategies; women might not be willing to occupy senior roles.

So, organizations today are challenged to offer to their staff flexible and innovative solutions that increase the productivity of their professional activities without detriment to the well-being, physical and psychological health, family, personal relationships and other aspects of their lives and improve organizational interaction and interpersonal relations of personnel in organizations.

The aim of the article is to analyse the main categories, resources and limitations of work-life balance, results of empirical study, main organizational and individual strategies for creating balance. So, we are going to discuss three tasks: 1) theoretical background of the work-life balance concept; 2) empirical measurement of work-life balance; 3 ) the basic strategies of work-life balance programs.

The first task was to analyse the theoretical background of the work-life balance concept. Work-life balance is a category defined by researchers as a person's subjective general assessment of the interrelation between work and other life areas, family, as well as the ability to combine these spheres in a proper way (Tkalych, 2015). In some modern research studies, a "work-life integration" term is also used. It reflects a fulfilled, healthy, and productive life, which combines work, relationship, entertainment; integrates a number of activity types focused on oneself, one's personal and spiritual development (Allen, 2013; Jones et al., 2008; Lockwood, 2003).

There are several terms, which describe work-life interface and interaction. For example, "work-life balance", "work-family balance", "work-life integration". All these terms are corresponded to each other, but the term "work-life integration" is more general and includes "work-life balance". And the term "work-life balance" includes "work-family balance".

The negative aspects of this interaction have been defined as work-family / work-life conflict T.D. Allen et al. (2013), B. Beham et al. (2014), U Kinnunen et al. (2014), V.K. Lim et al. (2014), M. Roche et al. (2010) and the positive as work-family / work-life enrichment T.D. Allen et al. (2013), M. Roche et al. (2010).

Work-life integration is a satisfying, healthy and productive life, that includes work, play, and love; that integrates a range of life activities with attention to self and to personal and spiritual development; and that expresses a person's unique wishes, interests and values. It contrasts with the imbalance of a life dominated by work, focused on satisfying external requirements at the expense of inner development, and in conflict with a person`s true desires.

Among the components that determine this balance, the researchers distinguish the following: time balance (equal distribution of time between work and life), the balance of the environment (the equivalent psychological force), the balance of pleasure (the same satisfaction from the professional and family roles). In our research we have been also singled out the following: load balance; job planning; complexity of the job; social contacts.

The main work-life balance components include the load balance (optimal number of business hours, possibility to distinguish between work and leisure, take a leave, not to think about work all day long); time balance (equal distribution of time spent for work and other life spheres); work time and content planning (the possibility to change the content of one's own work and to schedule business hours); the complexity of tasks (attractiveness, complexity, optimal number of tasks or challenges to be addressed); environment balance (equal psychological efforts aimed to solve occupational, family, or personal tasks); social intercourse (friendly relations with colleagues, director's support, absence of the sense of loneliness, satisfaction of the need for socializing at work); satisfaction balance (equal occupational and family life satisfaction) (Tkalych, 2015). The analysis and summary of the researches of T.D. Allen et al. (2013), B. Beham et al. (2014), T.K. Billing et al. (2014), R. Burke (1999), Y.-P. Chen et al. (2014), W.C. Marcinkus et al. (2007), , P. Rayman et al. (1999), M. Roche et al. (2010), B. Wille et al. (2013), which were devoted to the study of work-life balance / work-family conflict, enrichment of work-life interface, the determinants and consequences of unbalancing, allowed us to create a model of work-life balance.

Work-life conflict is a form of inter-role conflict whereby role pressures from the work and family domains are incompatible. Hence participation in one role is made more difficult by participation in other roles, such as work and family.

M. Roche et al. (2010) noted that the imbalance between work and family roles and the resultant conflict requires greater attention by researchers. Authors also found, that work-family and family - work conflict was negatively related to autonomy, while family - work conflict was also negatively related to competence and relatedness.

T.D. Allen et al. (2013), M.J. Grawitch et al. (2010), U. Kinnunen et al. (2014), A.M. Konrad et al. (2012), M. Roche et al. (2010), K.L. Scott et al. (2015) distinguished a number of causes of work-life conflict. 
Among them are role stressors, role-playing environment, social support, work and family characteristics, personal characteristics. Most causes of both types of conflicts are much more related to the work and its content than to the family or personal life.

Generalization and systematization of the causes of work-life conflict enabled us to make the key groups: 1) work-life conflict (Stressors of professional roles: role overload (lots of job tasks), role conflict, the amount of time, which devoted to work (working time requirements). Social support: lack of support from the organization (care for the welfare of employees), management and colleagues. Personality characteristics: neuroticism, external locus of control, destructive coping strategies, gender, the number of children. 2) Life work conflict (Stressors of personal and family roles: role overload ( lots of family responsibilities and tasks); role conflict (performing of conflicting multiple roles). Social support: low level of support from the partner or husband / wife, other family members. Personality characteristics (the same).

Work-life / life - work conflicts have many important negative outcomes for individuals, their personal life, families and organizations. T.D. Allen et al. (2013) distinguished among three different types of outcomes: 1) work-related outcomes (work dissatisfaction); 2) non-work-related outcomes (life dissatisfaction); 3) stressrelated outcomes (health problems, burnout, tiredness).

In addition, the other negative consequences of these types of conflicts include: absenteeism, staff turnover, low labour discipline, low motivation, lack of satisfaction in relationships, strives, stress, exhaustion, emotional burnout, depression, role conflicts, deterioration of physical health, increased job-injury rate among personnel.

Let's now talk about resources (work-life enrichment) of the work-life balance, which increase the level of balance between work and other spheres of employees' life: personal life, family, social activities, interests, hobbies. So, work-life enrichment includes such organizational resources: work autonomy; a variety of job tasks; investigation of opportunities and resources; social, organizational, leader and colleagues support; professional skills; direct and long-term results. Other physical, psychological, social and material resources of working environment.

Life-work enrichment includes such family, other areas of life resources: family, partner and friends support; relationship satisfaction; social activity, other physical, psychological, social and material resources of the personal life. Personality characteristics: extraversion, low level of neuroticism, personal flexibility.

Enriching work-life interaction (work-life outcomes) positively affects various areas of life, including job satisfaction, involvement in professional interaction, marital, family and personal relationships, productivity as well as psychological and physical health of the individual. Professional achievements lead to a sense of satisfaction that «transferred» to family and personal life, and enhance the pleasure of leisure activity. Performing multiple roles is a personal resource that enriches various spheres of life of the individual.

Satisfaction with work and family roles have been found to have additive effects on happiness, life satisfaction, and perceived quality of life. Empirical findings also suggest that involvement in multiple roles can improve psychological and mental health by buffering negative effects such as reduced.

There is a number of mechanisms of multiple roles that allow them to be a resource: the accumulation of role privileges; different roles may act as «buffer» to each other or offset each other; getting additional resources and improving performance of different roles; personal development and personal satisfaction through psychological experience gained from multiple roles.

P. Rayman et al. (1999) distinguished the enrichment of work-life balance: a positive impact on the achievements of the organization and the quality of life of employees; effective communication in the workplace, teamwork is necessary to change to be effective; employees work on their «real» work (real job tasks); employee engagement in cooperation enhances accountability and provides energy. It creates an efficient workflow and there are positive changes in organizational culture. Work on distance (phone, internet connection) enables better manage ones own time, family responsibilities.

According to T.D. Allen et al. (2013), C. Emslie C et al. (2009), M.R. Frone (2003), M.J. Grawitch et al. (2010), N.R. Lockwood (2003), L. Muse et al. (2008) work-life balance provides the following benefits for employees: time to focus on life outside of work; control of working life; employees feel that their life is in balance, their work is easier and more manageable; employees can manage their tasks better; they will be more motivated to work; stress levels among employees - employees, who have found the right balance between work and life, haven't worry about stress; employees would like to have more power because they feel better and feel, that they can handle it.

We also defined the benefits of work-life balance for the organization, which include: increasing of employees' motivation; balance helps employees feel valuable to the organization and improving productivity and loyalty; less stressful work environment; increasing competitiveness in the labour market, increasing the number of potential employees, reducing the number of absenteeism etc.; good reputation of the employer; the 
possibility of retraining employees, that also help to expand knowledge, to increase flexibility, to improve teamwork, to increase personal interaction, motivation, and communication.

Work-life balance programs have the potential to significantly improve employee morale, reduce absenteeism, and retain organizational knowledge, particularly during difficult economic times. In today's global marketplace, as companies aim to reduce costs, it falls to the human resource professional to understand the critical issues of work -life balance and champion work/life programs. Be it employees whose family members and/or friends are called to serve their country, single mothers who are trying to raise their children and make a living, Generation $\mathrm{X}$ and $\mathrm{Y}$ employees who value their personal time, couples struggling to manage dual-career marriages, or companies losing critical knowledge when employees leave for other opportunities, work-life balance programs offer a win-win situation for employers and employees.

The second task was to analyse the empirical measurement of work-life balance.

Methods and sample. In order to examine the level of work-life balance, we have designed an inventory based on 16 statements divided into the following 4 groups (which are the work-life balance components) by means of the factor analysis: 1) absence of the load balance; 2) work time and content planning; 3) professional tasks complexity; 4) social intercourse (Tkalych, 2015). The study has involved professionals from different fields of activity $(\mathrm{n}=1138)$. The number of women and men as well as their age distribution have been representative to the general number of participants.

Results. The work-life balance has been generally assessed as average $(M=4.19)$. It should be noted that they have scored the load balance lower $(\mathrm{M}=3.15)$ than other components: professional tasks complexity $(\mathrm{M}=$ 4.18), work and content planning $(M=4.46)$, and social intercourse $(M=4.98)$. It is the social intercourse component (friendly relations with coworkers $(M=4.65)$, the support of a manager $(M=4.91)$, the absence of the sense of loneliness $(M=5.36)$, satisfaction with socializing $(M=4.99))$ which has got the highest scores. Therefore, the social and communication components, interaction with a manager and colleagues are the most balanced ones and have been most positively assessed by the participants.

The research results have shown that there is a statistically significant relationship between the participant's age and their social intercourse scores $(\mathrm{p}<0.03)$ : it becomes more positively assessed with aging, while other balance components have no significant age differences. Age correlates with such work-life balance characteristics as work time planning $(\mathrm{p}<0.01)$, attractiveness and complexity or work and tasks $(\mathrm{p}<0.01)$, a number of tasks to be completed $(p<0.01)$, the absence of the sense of loneliness $(p<0.01)$, perception of colleagues as friends $(\mathrm{p}<0.01)$ : these indicators increase with aging.

The third task was to analyse the basic strategies of work-life balance programs. According to the results of the empirical study and to the theoretical approaches, the basic strategies in professional productivity increase programs in organizations may be the following: focus strategies, "resource/refusal" strategies, adaptive strategies, every of which is manifested in a certain kind of an individual strategy (Emslie et al., 2009; Frone, 2003; Grandey et al., 2010; Lyness, 2014; Muse et al., 2008, Straub, 2007; Tombari et al., 1999).

Focus strategies are the ones which demonstrate a direction or a way of solving problematic or stressful situations by co-workers.

"Resource / rejection» strategies: coping strategies are directly related to the "work-family" interaction: demands decrease and resource increase strategies.

- Demands decrease strategy works in the form of decreasing a number of business hours, refusing some occupational or family duties, defining the priorities, limiting social life, decreasing role expectations (for example, being "good enough" for business or family relations).

- $\quad$ Resources increase strategy provides searching for support both at home and work (authority delegation, allocation of home duties, communication, positive interaction, satisfaction with relationships), efforts of finding benefits, learning through complex situations, using proactive future-focused strategies (work week scheduling, interfamily resources search, proactive dialoguing with a partner or a director).

Adaptive strategies are the ones helping to adapt to problems arising at work or / and at home. home and vice versa;

Compensatory strategy - negative things or thoughts are compensated with positive energy at

- $\quad$ Segmentation strategy - negative thoughts caused by work issues do not affect family relations. Both strategies are adaptive in achieving the balance between work and life.

At the personal level, it is necessary to improve the decision-making process and communication within a family for professional roles optimization and role conflict harm elimination as well as elimination of stressors affecting other family members. A person must be sure his or her work does not harm his/her physical health allowing to devote enough attention to other life spheres.

Billing et al. (2014), Kinnunen et al. (2014), Scott et al. (2015) suggest the following interrelated levels of "work-life" integration disbalance: 
- $\quad$ time, energy, and duties: a person spends more time and energy for work rather than other life spheres, and has too many work duties;

intimacy; attitudes and behavior increase demands for professional skills and achievements, and eliminate

-

significance and criteria for self-assessment - a person has an image of the ideal self (the one he or she thinks he/she must be) and others' expectations, though as a rule, the achievement of such an image in real life is too exhausting for an individual.

In order to reach the work-life integration, a feeling of life fullness, some changes should cover the following three stages: the first one is balancing time, efforts, and duties; the second one is integration of occupational mastery and intimacy with others; and the third one is self-focus, which means being focused on one's own self-esteem, aspirations, and self-image.

These changes are possible upon condition of psychological support programs, sports psychologists' work who help to form the corresponding abilities and skills, as well as significant personal traits of professionals: motivation, self-confidence, persistence, psychological flexibility, lability, a low neuroticism level.

Besides, according to research, active engagement into the interaction with family and entertainment after a business day contribute to a better recovery as compared to passive activities (Jones, 2008).

One more important task regarding individual strategies of the balance achievement is the resources personal allocation. Resources personal allocation is a strategy according to which all desirable or necessary requirements are considered to stimulate a person to make a choice of where, when and how he or she spends resources in life (Grawitch et al., 2009). The efficient resources personal allocation not only decreases negative consequences but also contributes to positive results in the work-life balance achievement. It includes the following four stages: 1) defining available personal resources, 2) laying down requirements for work and private / family life, 3) using efficient strategies of resources allocation; 4) results review.

This task is often ignored in one's work and private life in cases when work requires performing professional duties which contradict the family ones, ignoring other requirements for personal resources (e. g. social or private life, other activities, religious requirements, sports, rest, etc.). Individual differences, external resources, human-environment interaction have a great impact on the resources personal allocation. Despite the fact external resources are diverse, in general they can be divided into two basic spheres: support as well as teaching and development of a personality.

We have also identified the following conditions for the implementation of work-life balance programs and strategies:

- involving personnel at all levels - from management to employees (including diagnosis of the current situation of gender interaction, gender discrimination, the work-life balance);

- team approach that involves interrelated processes at all organizational levels;

- clear indicators of job performance and quality of life of the personnel;

- warranty for the personnel: increase productivity and improve interactions will not limit the professional and personal achievements and income; eliminating gender discrimination against one group does not provide its appearance on another;

- remuneration: all participants are recognized and rewarded for the risk and creativity that enable the creation and implementation of programs;

- communication: clear mechanism, positive, harmonious way of interaction, information transmission, view on the problems;

- the inclusion of the work-life balance concept, training of gender interaction for the personnel into the HR strategy of the organization.

Conclusions. Using work-life interface benefits as a result of work-life balance programs for personnel is not a career-limiting move. In fact, work-life interface benefits replenish employee resources in the form of time, energy, and motivation, and users of these benefits receive more promotions than their non-using counterparts. The support for sustained job commitment and performance over time provided by flexibility benefits appears to be more important to career outcomes than any initial negative stigma that might be attached to employees who request a work-life accommodation.

The basic possible individual work-life balance achievement strategies are as follows: focus strategies, "resource-refusal" strategies, adaptive strategies, every of which is manifested in a certain kind of an individual strategy. The use of the adaptive individual strategies with the resource increase strategy perfectly contributes to the work-life balance achievement. We believe that the main personal skills and traits contributing to the worklife balance achievement include the following ones: personal flexibility, a high level of self-discipline; trust- 
based relations; dynamic and independent work. These skills should be mature, and the work-life balance achievement psychological teaching programs for personnel can increase their level.

Further steps in the study of work life balance are to analyze this phenomenon in the context of the psychological well-being of personnel.

\section{References}

1. Allen, T. D. (2013). The Work-Family Role Interface: A Synthesis of the Research from Industrial and Organizational Psychology. In I. B. Weiner (Ed.) Handbook of Psychology (pp. 698-718). John Wiley \& Sons, Inc. ISBN: 978-0-470-61904-9

2. Beham, B., Drobnic, S., \& Prag, P. (2014). The work-family interface of service sector workers: a comparison of work resources and professional status across five European countries. Applied Psychology: an International Review, 63(1), 29-61.

3. Billing, T. K., Bhagat, R. S., Babakus, E., \& Krishnan, B. (2014). Work-Family Conflict and Organisationally Valued Outcomes: The Moderating Role of Decision Latitude in Five National Contexts. Applied Psychology: an International Review, 63(1), 62-95.

4. Burke, R. (1999). Are families a career liability? Women in Management Review, 14(5), 159-163.

5. Chen, Y-P., Shaffer, M., Westman, M., Chen, S.H., Lazarova, M., \& Reiche, S. (2014). Family Role Performance: Scale Development and Validation. Applied Psychology: an International Review, 63(1), 190-218.

6. Emslie, C., \& Hunt, K. (2009). 'Live to Work' or 'Work to Live'? A Qualitative Study of Gender and Work-life Balance among Men and Women in Mid-life. Gender, Work and Organization, 16(1), January, 151-172

7. Frone, M. R. (2003). Work-family balance. In J. C. Quick \& L. E. Tetrick (Eds.), Handbook of occupational health psychology (pp. 143-162). American Psychological Association.

8. Grawitch, M. J., Barber, L. K., \& Justice, L. (2010). Rethinking the Work-life Interface: It's Not about Balance, It's about Resource Allocation. Applied psychology: health and well-being, 2(2), 127-159

9. Grandey, A. A., Cordeiro, B. L., \& Crouter, A. C. (2005). A longitudinal and multi-source test of the work-family conflict and job satisfaction relationship. Journal of Occupational and Organizational Psychology, 78, 1-20

10. Hamilton, E. A., Gordon, J. R., \& Whelan-berry, K. S. (2006). Understanding the work-life conflict of never-married women without children. Women in Management Review, 21(5), 393-415.

11. Kinnunen, U., Rantanen, J., Mauno, S., \& Peeters, M.C.W. (2014). Work-Family Interaction. In M.C.W. Peeters (Ed.) An introduction to contemporary work psychology (pp. 267-289). Wiley Blackwell.

12. Konrad, A.M., \& Yang, Y. (2012) .Is using work-life interface benefits a career- limiting move? An examination of women, men, lone parents, and parents with partners. Journal of Organizational Behavior, 33, 1095-1119.

13. Kropf, M. B. (1999). Flexibility initiatives: current approaches and effective strategies. Women in Management Review, 14(5), 177-185.

14. Lim, V.K.G., \& Kim, T-Y. (2014). The Long Arm of the Job: Parents' Work-Family Conflict and Youths' Work Centrality. Applied Psychology: an International Review, 63(1), 130-150.

15. Lockwood, N.R. (2003) Work / Life Balance: Challenges and Solutions. Society for Human Resource Management.

16. Lyness, K. S., \& Judiesch, M. K. (2014). Gender Egalitarianism and Work-life Balance for Managers: Multisource Perspectives in 36 Countries. Applied Psychology: an International Review, 63(1), 96-129.

17. Marcinkus, W. C., Whelan-berry, K. S., \& Gordon, J. R. (2007). The relationship of social support to the work-family balance and work outcomes of midlife women. Women in Management Review, 22(2), 86-111.

18. Masuda, A. D., Poelmans, S. A., Allen, T. D., \& Spector, P. E. (2012). Flexible Work Arrangements Availability and their Relationship with Work-to-Family Conflict, Job Satisfaction, and Turnover Intentions: A Comparison of Three Country Clusters. Applied psychology: an international review, 61(1), 1-29.

19. Muse ,L., Harris, S. G., Giles, W. F., \& Field, H. S. (2008). Work-life benefits and positive organizational behavior: is there a connection? Journal of Organizational Behavior, 29, 171-192.

20. Rayman, P., Bailyn, L., \& Dickert, J. (1999). Designing organizational solutions to integrate work and life. Women in Management Review, 14(5), 164-176.

21. Roche, M., \& Haar, J. M. (2010). Work-Family Interface Predicting Needs Satisfaction: The Benefits for Senior Management. e-Journal of Social \& Behavioural Research in Business, 1(1), 12-23.

22. Scott, K. L., Ingram, A., Zagenczyk, T. J., \& Shoss, M. K. (2015). Work-family conflict and social undermining behaviour: An examination of PO fit and gender differences. Journal of Occupational and Organizational Psychology, 88, 203-218.

23. Smithson J., \& Stokoe E. H. (2005). Discourses of Work-life Balance: Negotiating 'Genderblind' Terms in Organizations. Gender, Work and Organization, 12(2), March, 147-168.

24. Straub, C. (2007). A comparative analysis of the use of work-life balance practices in Europe. Women in Management Review, 22(4), 289-304

25. Tombari, N., \& Spinks, N. (1999). The work-family interface at Royal Bank Financial Group: successful solutions - a retrospective look at lessons learned. Women in Management Review, 14(5), 186-193.

26. Tkalych, M., Snyadanko, I., Guba, N., \& Zhelezniakova, Yu. (2020). Social and psychological support for personnel in organizations: work-life balance programs. Journal of Intellectual Disability - Diagnosis and Treatment, 8(2), 159-166. 
27. Wille, B., De Fruyt, F., \& Feys, M. (2013). Big Five Traits and Intrinsic Success in the New Career Era: A 15-Year Longitudinal Study on Employability and Work-Family Conflict. Applied Psychology: An International Review, 62(1), 124-156.

28. Jones, F., Burke, R.J., \& Westman, M. (2008). Work-Life Balance. A psychological Perspective. Psychology Press, ISBN 978-1841695297

\section{Information about the author}

Ткалич Маріанна Григорівна, доктор психологічних наук, професор кафедри психології Інституту підготовки кадрів ДСЗУ, Київ, Україна

Tkalych Marianna G., PsyD, Professor, Ukrainian State Employment Service Training Institute, Kyiv, Ukraine E-mail: mtkalych@gmail.com

ORCID ID: https://orcid.org/0000-0003-4101-9659,

Отримано 12 жовтня 2021 p. Рецензовано 20 жовтня 2021 p. Прийнято 22 жовтня 2021 p. 